\title{
FACTORS INFLUENCING INDONESIAN INTERNET USERS INTENTION ON BUYING BOOKS ONLINE
}

\author{
Beatrik Messah ${ }^{1}$
}

\begin{abstract}
The purpose of this research is to discover and analyse factors influencing Indonesian internet users intention on buying books online. Certain factors will be investigated are demographic, features, convenience, web design, and security. This research used questionaires to obtain data from the respondents. After the data collected, SPSS software is used to process the data with using Chi-Square test. The result found that features, convenience, and security factors of online bookstores and level of education, income, and occupation of the Indonesian Internet Users influence the people intention on buying books online. In the other hand, web design of the online bookstores and the age of the Indonesian internet users have no influence on their intention on buying books online.
\end{abstract}

Keywords: internet user, online books

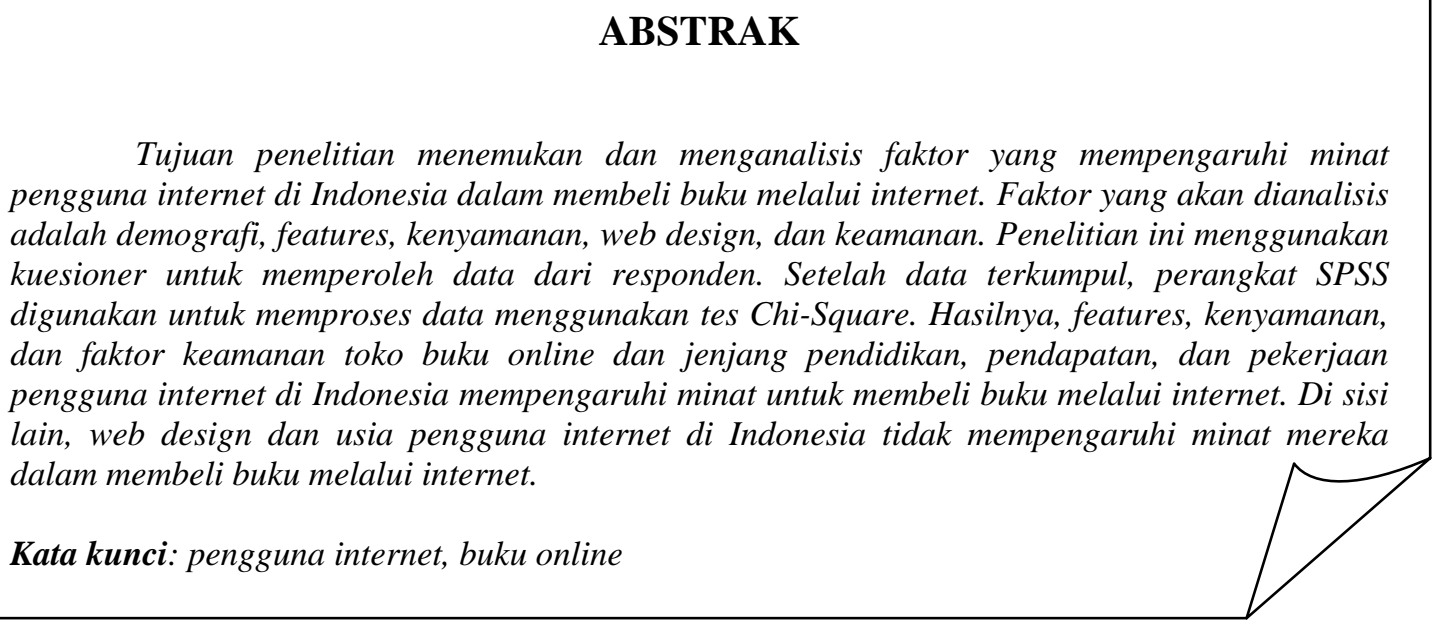

${ }^{1}$ Staf Pengajar Jurusan Manajemen, Fakultas Ekonomi, UBiNus, Jakarta 


\section{INTRODUCTION}

The rapid development of Information Technology has brought many new inventions which one of it that currently become the global trend in all over the world is internet. The emerged of internet has given some dramatically changes in the human life aspects. The significance changes are appearing by the way people used to socialize or do transactions with others. From general activities like chatting, writing email, to business activities such as Electronic Commerce. With E-commerce people are able to do their shopping tasks through the Internet, which known as online shopping. According to National Retail Federation, it is projected that online shopping will grow from \$11 billion in 1999 to \$41 billion in 2002 (Sunarsip, April 2001). In Indonesia, there are 2 million people which can be categorized as Internet User in Indonesia (Anonymous 4, 2001).

One of the commodities that commonly sold online are books. Nowadays, there are many available bookstores that offer on-line shopping via their home pages. It means that the customers can view their home pages from home, browsing the subjects, read the synopsis, until they find out what they want and order it. The bookstores will deliver their subscriptions in the next several days with additional transportation fee for some stores, while other offer free transportation fee. In Indonesia, a bookstore that is became the pioneer of E-commerce in Indonesia was an online bookstore called Sanur (Boerhanoeddin, 2000). This research will explore the impact of those factors, which are Demographic, Features, Web design, Convenience, and Security on changing the intention of the internet user to do on line shopping. By knowing the relation between those factors with the internet user behavior, other virtual market can managed their way of selling online, and improve their performance in order to attract more consumers, which in the end will increase their profit margin.

\section{Research Problems}

This research tries to explore and find out whether demographic factors, feature, layout, and security of online bookstores have influence on Indonesian Internet users Intention on buying books on-line. From the factors above, the research problems arise and become the research questions in this research are as follows.

1. Do the Demographic factors, such as: age, education, occupation, and income, have influence in Internet Users Intention on buying books online?

2. Do the features of online bookstores such as: the book's catalog, Help/Customer service, search function, special offer/discount price, shopping chart, book's synopsis, and readers review have affect in influencing Internet user Intention in deciding on buying book online?

3. Do the Web Design factors such as colors, web store' artistic value, layout, typography and visuals can influence Indonesian Internet users intention on buying books online?

4. Do the Convenience factors such as no time and place limitation, wide variety choices, convenience of accessibility, and easiness of prince comparison have influence Internet users Intention on buying books online?

5. Do the security issues, which can be see from the security of payment, security of personal information have influence in influencing Indonesian Internet users intention on buying books online? 


\section{Literature Review}

\section{Internet}

There are some different interpretations of the term of internet. Following is the term of the internet stated by Federal Networking Council in the Internet Monthly Reports, October 1995:

“ "Internet" refers to the global information system that is logically linked together by a globally unique address space based on the Internet Protocol (IP) or its subsequent extensions/follow-ons; is able to support communications using the Transmission Control Protocol/Internet Protocol (TCP/IP) suite or its subsequent extensions/follow-ons, and/or other IP-compatible protocols; and provides, uses or makes accessible, either publicly or privately, high level services layered on the communications and related infrastructure described herein” (Federal Network Council, 1995).

Internet can be understood as the network of networks, which consists several computers through wireless medium, which made the computers able to "communicate" each other. Because the computers are able to interact with each other, people can use them to send messages, gather information, or do two-way communication.

\section{Internet in Indonesia}

It was predicated that the Internet user in Indonesia would achieve almost 2.5 million people in 2001 (Manajemen, 2001). There are some controversies of the history of Internet in Indonesia. According to dotcom, an Internet magazine, Indonesia has connected to the Internet through UINET network. But the history record that Indonesia was officially have gathered with the Internet in 1993, which notified by received the ID domain. Following the recognition, the first ISP (Internet Service Provider) in Indonesia was built in 1994, which is Indonet (DotCom, 2001).

\section{E-commerce Overview}

E-commerce can be defined as "the buying and selling information, products and services via computer networks (Ravi, Whinston, 1996). We can broaden the definition by saying that Ecommerce is the concept of doing business transaction through the Internet and digital infrastructure. E-Commerce is a dynamic set of technologies, applications, and business process that link enterprises, consumers, and communities through electronic transactions and the electronic exchange of goods, services and information (Purbo, Wahyudi, 2001). 
The model of E-commerce (integrated perspective) as described by Nissen E. Mark are as follows.

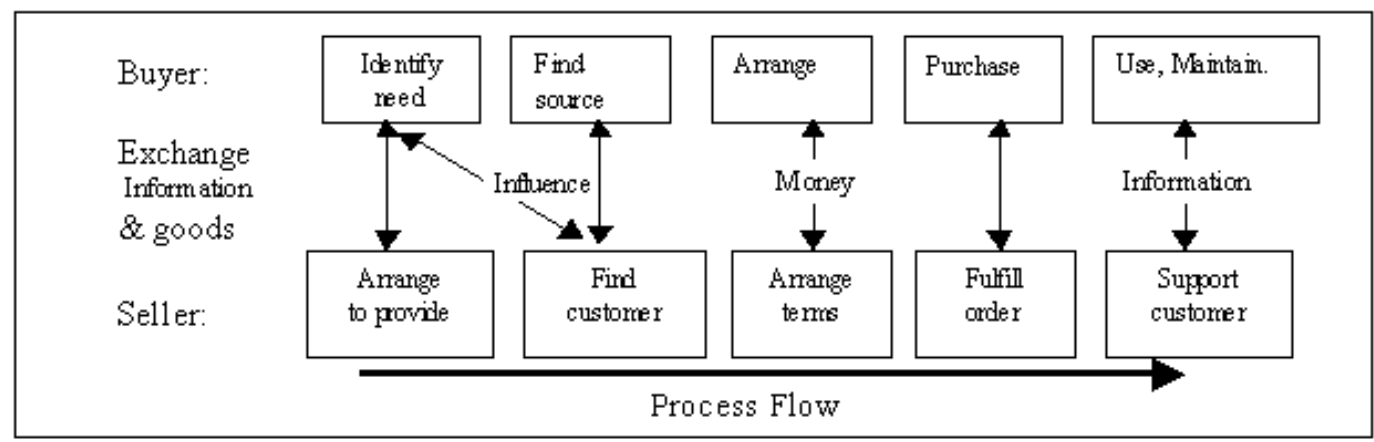

So urce : Nis sen E. Madk, 1995

Figure 1 Model of e-Commerce by Nielsen E. Mafk

There are two types of E-commerce; the first one of Business to business and the other is Business to Consumers. The first one type means that the transactions were happened between companies. Either the first company becomes the buyer or the seller; this kind of E-commerce usually involves big transactions. The second type of E-commerce is Business to Consumers. In this type the company do the transactions directly to the consumers as the buyers.

\section{E-Commerce Influences on Marketing}

The rapid growth of technology has given some changes in the way people doing their business activities. According to Kotler (2000), with the trend of E-commerce, sales produced through traditional direct-marketing channels have been growing rapidly. As he describe the definition of Direct Marketing as: "An interactive marketing system that uses one or more advertising media to affect a measurable response and/or transaction at any location" (Kotler, 2000).

Thus, the presence of E-Commerce has influence the way people do marketing activities to sell and promote their products. As Kotler also mention the description of Electronic Market which can be determined as another result from the influences of E-Commerce which change the way people market and sell their products.

\section{Consumer Behavior}

The way people decided to buy something from a store is very influenced by their buying behavior. There are many factors that influence the people buying behavior that are: Cultural, social, personal, and psychological factors. Cultural factors can be further divided to three factors that are culture, subculture, and social class. Social factors can be divided to reference groups, family and social roles and statuses. Personal factors can be influenced by personal characteristics, which are include the buyer's age, and stage in the life cycle, occupation, economic circumstances, lifestyle, and personality and self-concept. Finally, the psychological factors can be influenced by four major psychological factors, which are motivation, intention, learning and beliefs and attitudes (Kotler, 2000). 


\section{Purchase Decision}

There are many factors that can influence people decision of buying the products. Mostly people will directly buy the well know product from well-known store. But, there are two factors can intervene between the purchase intention and the purchase decision.

The first factor is the attitudes of others. The extend to which another person's attitude reduces one's preferred alternative depends on two things: The intensity of the other person's negative attitude toward the consumer's preferred alternative; and the consumer's motivation to comply with the other person's wishes. Kotler (2000). So the attitude from other people surround the prospective customers will give big influence in the customer intention before he decide to do online shopping or not.

The second factor is unanticipated situational factors that may erupt to change the purchase intention (Kotler, 2000). The steps of the purchase decision can be seen through the figure below.

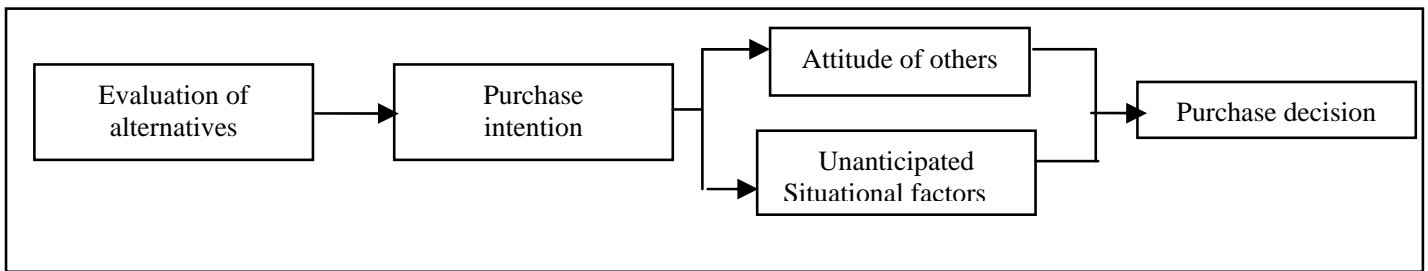

Source: Kotler (2000)

Figure 2 Steps of the Purchase Decision

\section{Factors that influences On-line Shopping}

\section{Barriers That Inhibit People Buy Online}

There are some factors that become inhibitor for people to do on-line shopping. As the research done by Pulse of The Customer, there are some reasons that become the barriers for consumers to buy on-line (Anonymous 1, 1999), those factors are as follows.

1. Some products are simply not conducive to an online purchase.

2. Shoppers are distrustful of the ability to handle returns and other customer service issues online.

\section{Factors That Influence People to Buy Online}

To persuade people to change their intention, a company must know what factors can influence the behavior of prospective customer. Online store can have more advantages from land store depend on the way they manage the online store. According to the research conduct by PriceWaterHouse Coopers, the task of creating a satisfying shopping experience online is different from the offline stores. There are some elements called as "The Eight S's" that can make a 
satisfying online shopping Experience (Anonymous 3, 2001): Selection, substance, savings, simplicity, sensory appeal, speed, service, security.

Surveyed conducted by Danish E-Commerce Association (Nielsen, 1999), found that there are some reasons why people shop on the web which are as follows.

1. $\quad$ Easy to place and order (83\%).

2. Large selection of products (63\%).

3. Cheaper prices (63\%).

4. Faster service and delivery (52\%).

5. Detailed and clear information about what is being offered (40\%).

6. No sales pressure (39\%).

7. Easy payment procedures (36\%).

\section{The Importance of Site Features}

When building an online shop, the Webmaster must really give attention to the features of the future site. According to the survey conduct by PriceWaterHouseCooper, indicates that not only are the features of the site important to online shoppers when selecting an online shopping site, but they can also help retailers turn shoppers into buyers, while other can pull the shoppers away (Anonymous 3, 2001).

According to eCom Resource Center, it is important to notify how a storefront is composed, how a good catalogue should be, how about the online shopping chart, and payment options. (eCom Resource Center, 2001). According to the survey, it is indicated that features are important to influence people behavior to buy something online. Below are factors that can be involve in the site features to help make a retail Web site a success (O’Brien, 1999).

1. Performance and service

2. Personalization

3. Socialization

4. Look and feel

5. Incentives

From other surveyed sponsored by the Danish E-Commerce Association (Nielsen, 1999). Three of the features that can attract people to buy online are as follows.

1. Detailed information about the product itself

2. Price comparisons

3. Detailed information about the vendor

Specifically, in buying books online, there are some factors that can increase people's intention to buy books from the online bookstores such as (Sembiring, 2001) bellows.

1. Always providing new books' edition

2. Giving essential price differences

3. Company's profile

4. Books' synopsis

\section{The Importance of Web Design}

There are six non-technical things that crucial to bear in mind as we design a web site (Anonymous 3, 2001) which are bellows. 


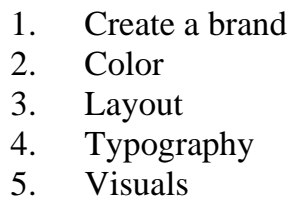

\section{The Importance of Security}

\section{Security of Payment}

According to Retail Intelligence Systems consumer survey (2001), concerns surrounding security topped the list of online shopping barriers. Approximately 69\% of consumers with online access indicated that they were concerned about credit card security. Security must be built-in at both the technical and business process level. At the technical level, data vulnerabilities while in transit are usually dealt with though a combination of encryption schema and transmission protocols such as Secure Sockets Layer (SSL) (Fingar, et al 2000).

Wahyudi (2001) also describe about Secure Electronic Transaction (SET) which was developed by the collaboration between Visa and Mastercard. SET was covered the protocol specification and infrastructure which support the payment system using bank card payments. There are three type of payment category as describe by Wahyudi (2001) which are as follows.

a. Digital cash with credit card basis.

b. Digital cash with check type.

c. Digital cash with cash payment type.

\section{Security of Personal Information}

Approximately $61 \%$ of consumers indicated that they were concerned that online shopping sites would not keep their personal information private (Anonymous 3, 2001). The security of personal information can be very influenced in build consumers' intention to buy online from the web store. A customer concerned with privacy issues is more likely to feel secure about parting with her personal information once she becomes familiar and comfortable with an online retailer. She might well be swayed by a polite request to enable her browser's cookies or to register as a site user after some experience with the site and after a compelling explanation of the benefits associated with sharing her information. In contrast, forcing a customer to enable cookies or divulge personal information in order to use basic site features may well encourage her to click to a competitor's site (Anonymous 3, 2001).

\section{Buying Books Online}

As described in the survey conducted by Verdict (Anonymous 2, 2000). It also stated that online books selling still in the second place from the amount sales, under the travel industries, which could be categorized as service. The main categories of retail goods being bought are bellows.
1. Books (54\%)
2. Music and video (34\%)
3. Computer software (34\%)
4. Clothing/footwear trails at $16 \%$, with food/drink at $8 \%$ 


\section{Methodology}

\section{Population and Samples}

The respondents that will become the target of the data collection are the internet users in Indonesia. The data collections are begin at August 2001, with the period of one-month data collection.

\section{Sampling Techniques}

Using questionnaires that are paper based or traditional and email based or on-line questionnaires. The numbers of questionnaires that distributed are 350 questionnaires. The type of questionnaires used is the close model. The traditional questionnaires were distributed directly to the Internet users in Indonesia, specifically in the bookstores, which equipped with the Internet Café. The online questionnaires were distributed to the people whose names were listed in the online bookstores' guest books.

\section{Research Model}

The model used in this research is constructed using the combination of the factors stated in previous survey and findings such described in the literature review. Using some changes and modification, the factors is created to be appropriated with the research scope.

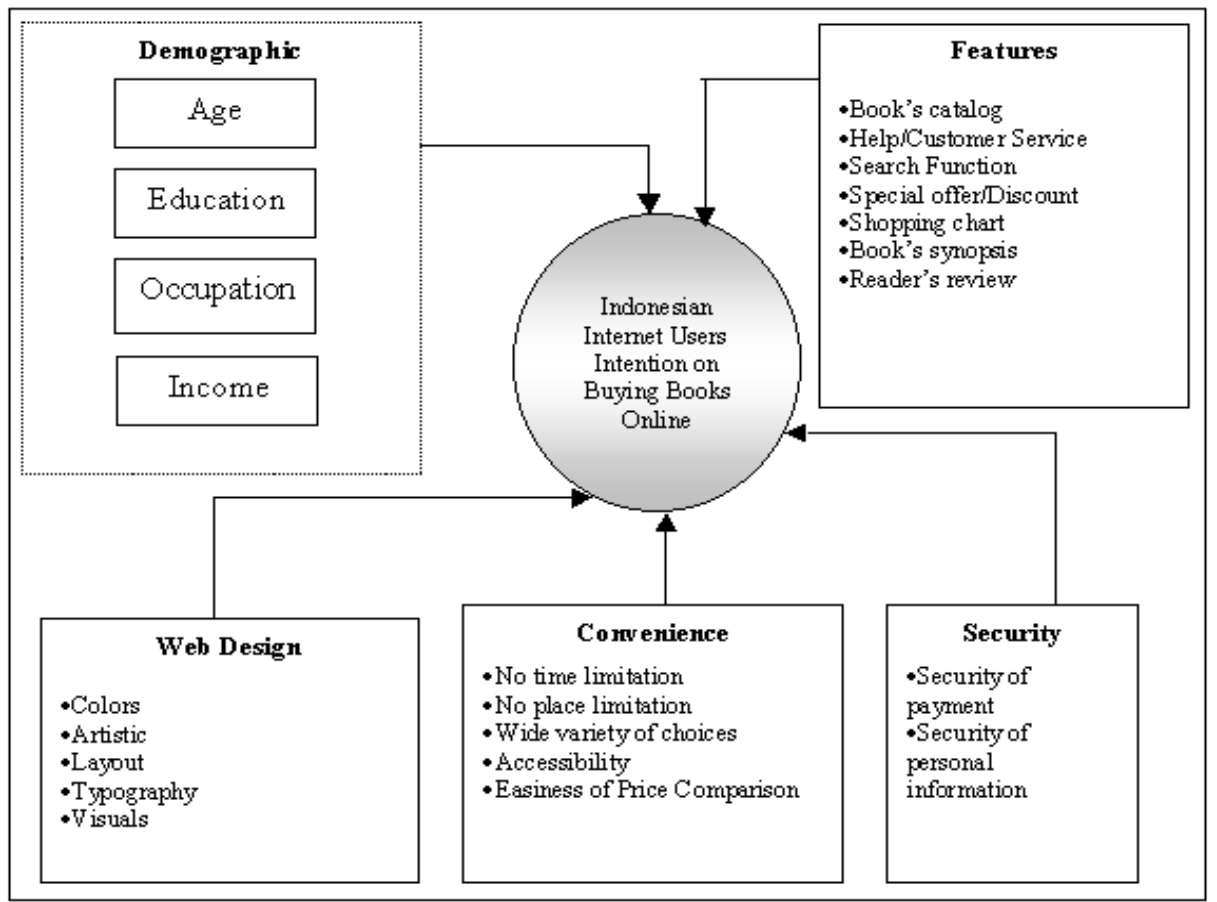

Figure 3 A Research Model 


\section{Research Variables}

\section{Independent Variables}

The independent variables used in this research are the factors that assumed to have impact toward the Indonesian Internet users intention on buying book online. Those factors are the Demographic factors, features of the online bookstores, Web Design, convenience, and security. The features, convenience, and security factors will be scaled from very disagree to very agree, while web design factors will be scaled from very poor to very good; and users intention scaled from very low to very high. The information of each variable is bellows.

$\mathrm{X} 1=$ Features factors which will be measure from the respondent think about the book catalog, Help/Customer service, search function, special offer/discount, shopping chart, book synopsis, readers review of the online bookstores.

$\mathrm{X} 2$ = Web Design which is contain with factors of colors; the easy navigation site, layout, typography, and visuals.

$\mathrm{X} 3$ = Convenience which is the time efficiency, no time and place limitation, the price, wide variety choices, and easiness of the online bookstores.

$\mathrm{X} 4$ = Security which is related to the security of payment, security of personal information/privacy and security message/certification of the protection use by the store.

$\mathrm{X} 5$ = The Indonesian Internet Users range of Age

X6 $=$ The Indonesian Internet Users' level of Education

$\mathrm{X} 7$ = The Indonesian Internet Users' type of occupation

$\mathrm{X} 8=$ The Indonesian Internet Users' range of Income

2. Dependent Variables

$\mathrm{Y}=$ Indonesian Internet users intention on buying books on-line.

\section{Hyporesearch}

1. First Hyporesearch

Ho $=$ The Feature factors of the online bookstores do not influence the users intention on buying books online

$\mathrm{H} 1=$ The Feature factors of the online bookstores do influence the users intention on buying books online

2. Second Hyporesearch

Ho $=$ The Web Design factors of the online bookstores do not influence the users intention on buying books online

H1 = The Web Design factors of the online bookstores do influence the users intention on buying books online

3. Third Hyporesearch

Ho $=$ The Convenience factors of the online bookstores do not influence the users intention on buying books online

$\mathrm{H} 1=$ The Convenience factors of the online bookstores do influence the users intention on buying books online 
4. Fourth Hyporesearch

Ho $=$ The Security factors of the online bookstores do not influence the users intention on buying books online

$\mathrm{H} 1=$ The Security factors of the online bookstores do influence the users intention on buying books online

5. Fifth Hyporesearch

Ho $=$ The Indonesian Internet users' range of Ages do not influence their intention on buying books online

H1 = The Indonesian Internet users' range of Ages do influence their intention on buying books online

6. Sixth Hyporesearch

Ho $=$ The Indonesian Internet users' education level do not influence their intention on buying books online

H1 = The Indonesian Internet users' level of education do influence their intention on buying books online

7. Seventh Hyporesearch

Ho $=$ The Indonesian Internet users' occupation do not influence their intention on buying books online

H1 = The Indonesian Internet users' occupation do influence their intention on buying books online

8. Eighth Hyporesearch

Ho $=$ The Indonesian Internet users' range of income do not influence their intention on buying books online

H1 = The Indonesian Internet users' range of income do influence their intention on buying books online

\section{DISCUSSION}

\section{Respondents}

In this research the total questionnaires distributed either online or traditional form are 350. The questionnaire that are received back are 174, with 23 questionnaires are not valid. Therefore, in this research there are 151 questionnaires that can be used for further analysis. The respondents are Internet users in Indonesia, and the data collection period is about one month.

\section{Descriptive Statistics}

Respondents fill the questionnaires are mainly have aged from 25 to 34 years old or about 43.7 percent. 84 people are male or about 55.6 percent from the total respondents. The respondents are mostly having bachelor degree or about 63.6 percent. The occupation of the respondents mostly is employee (68.2 percent), with the range of income of more than 2 million to 5 million (42.4 percent). The 31.1 percent of the respondents access the Internet every day. The most well 
known online bookstores is Amazon (44.4 percent), while Gramedia Cyberstore is on the second place, with 34.4 percent. From the research, it found that about 47,7 percent of the respondents have high intentions to buy books online, while 45.7 percent have moderate intention level.

\section{Summary of Analysis Result}

From the data analysis, it yield that the only factors that not influence the Internet Users Intention of buying books online is web design. While feature, convenience and security have influencing effects to the users' buying intention. And from Kendall's Tau-B analysis, the security factors have the highest influencing affect on the users buying intention.

Each of online bookstores offers different features with other stores. The basic features offers by most of the online bookstores are book catalogue, search function and online customer service. Some of the bookstores offer additional features that can attract their customers, such as book synopsis, reader review section, and discount price. From the research, customers are mostly attracting with the discount price offer by the online bookstores.

Web design of the online bookstores, is the appearance of the online bookstores' web site. This factor is involved of color, layout, typography, visuals, and navigability of the online bookstores' web site. From the analysis, it is found that the web site factors do not influence the Indonesian Internet users intention on buying books online. This means that regardless of how the appearance of the online bookstores, people are more attract to shop there if the stores can offers high performance of features, convenience and security. Convenience factors also influence the intention of the Internet users of buying books online. The people have intention to buy books online, because the can received many advantages and benefit, which they can't get from the traditional bookstores. Such as time efficiency, and least physical effort, by buying books online they don't need time to go to the traditional bookstores, find parking space, and moreover they can do their shopping whenever and wherever they want. All of these convenience factors influence their intention of buying books from online bookstores.

The highest influence is come from security factors. In this research the security factors is divided into two types of security, which is security of payment and security of personal information. All of this factor play significance role in building high intention for the Internet Users to buy books online. The personal information security of the Internet users also play important role in building positive intention of the prospective customers. The summary of analysis result is such as shown by the table below: 
Table 1 Summary of the Analysis Result

\begin{tabular}{|c|c|c|c|c|c|c|c|c|}
\hline Hyporesearch & $\begin{array}{l}\text { Types of } \\
\text { Variables }\end{array}$ & $\begin{array}{l}\text { Degree of } \\
\text { Freedom } \\
\text { (df) }\end{array}$ & $\begin{array}{l}\text { Calculated } \\
\text { Chi-Square } \\
\text { Value } \\
\end{array}$ & $\begin{array}{l}\text { Table } \\
\text { Chi- } \\
\text { Square } \\
\text { Value } \\
\end{array}$ & $\begin{array}{l}\text { Kendall's } \\
\text { tau-b }\end{array}$ & $\begin{array}{l}\text { Contingency } \\
\text { Coefficient }\end{array}$ & $\begin{array}{l}\text { Accept/ } \\
\text { Reject } \\
\text { Ho }\end{array}$ & / Result \\
\hline $\begin{array}{l}\text { First } \\
\text { Hyporesearch }\end{array}$ & $\begin{array}{l}\text { Ordinal } \\
\text { Ordinal } \\
\end{array}$ & 6 & 49.28 & 10.645 & 0.508 & & $\begin{array}{l} \\
\text { Reject } \\
\text { Ho } \\
\end{array}$ & $\begin{array}{l}\text { The Feature factors } \\
\text { of the online } \\
\text { bookstores do } \\
\text { influence the user } \\
\text { intention toward } \\
\text { buying books online }\end{array}$ \\
\hline $\begin{array}{l}\text { Second } \\
\text { Hyporesearch }\end{array}$ & $\begin{array}{l}\text { Ordinal } \\
\text { Ordinal } \\
\end{array}$ & 9 & 13.965 & 14.684 & 0.314 & & $\begin{array}{l} \\
\text { Accept } \\
\text { Ho } \\
\end{array}$ & $\begin{array}{l}\text { The Web Design } \\
\text { factors of the online } \\
\text { bookstores do not } \\
\text { influence } \\
\text { Indonesian Internet } \\
\text { users intention } \\
\text { toward buying } \\
\text { books online }\end{array}$ \\
\hline $\begin{array}{l}\text { Third } \\
\text { Hyporesearch }\end{array}$ & $\begin{array}{l}\text { Ordinal } \\
\text { Ordinal }\end{array}$ & 9 & 57.903 & 14.684 & 0.405 & & $\begin{array}{l} \\
\\
\text { Reject } \\
\text { Ho }\end{array}$ & $\begin{array}{l}\text { The Convenience } \\
\text { factors of the online } \\
\text { bookstores to } \\
\text { influence the } \\
\text { Indonesian Internet } \\
\text { users intention on } \\
\text { buying books online }\end{array}$ \\
\hline $\begin{array}{l}\text { Fourth } \\
\text { Hyporesearch }\end{array}$ & $\begin{array}{l}\text { Ordinal } \\
\text { Ordinal } \\
\end{array}$ & 9 & 62.719 & 14.684 & 0.551 & & $\begin{array}{l} \\
\\
\text { Reject } \\
\text { Ho } \\
\end{array}$ & $\begin{array}{l}\text { The Security factors } \\
\text { of the online } \\
\text { bookstores do } \\
\text { influence the } \\
\text { Indonesian Internet } \\
\text { users intention on } \\
\text { buying books online }\end{array}$ \\
\hline $\begin{array}{l}\text { Fifth } \\
\text { Hyporesearch }\end{array}$ & $\begin{array}{l}\text { Nominal - } \\
\text { Ordinal }\end{array}$ & 9 & 10.773 & 14.684 & & 0.258 & $\begin{array}{l} \\
\text { Accept } \\
\text { Ho }\end{array}$ & $\begin{array}{l}\text { The Age of } \\
\text { Indonesian Internet } \\
\text { Users do not } \\
\text { influence the Users } \\
\text { intention toward } \\
\text { buying books online }\end{array}$ \\
\hline $\begin{array}{l}\text { Sixth } \\
\text { Hyporesearch }\end{array}$ & $\begin{array}{l}\text { Nominal - } \\
\text { Ordinal }\end{array}$ & 9 & 49.264 & 14.684 & & 0.496 & $\begin{array}{l}\text { Reject } \\
\text { Ho }\end{array}$ & $\begin{array}{l}\text { The Education level } \\
\text { of Indonesian } \\
\text { Internet Users do } \\
\text { influence the Users } \\
\text { Intention toward } \\
\text { buying books online }\end{array}$ \\
\hline $\begin{array}{l}\text { Seventh } \\
\text { Hyporesearch }\end{array}$ & $\begin{array}{l}\text { Nominal - } \\
\text { Ordinal }\end{array}$ & -12 & 38.203 & 18.549 & & 0.449 & $\begin{array}{l}\text { Reject } \\
\text { Ho }\end{array}$ & $\begin{array}{l}\text { The Occupation of } \\
\text { Indonesian Internet } \\
\text { Users do influence } \\
\text { the Users Intention } \\
\text { toward buying } \\
\text { books online }\end{array}$ \\
\hline
\end{tabular}




\begin{tabular}{|c|c|c|c|c|c|c|c|}
\hline Eight & Nominal & & & & & Reject & $\begin{array}{l}\text { The Income of } \\
\text { Indonesian Internet } \\
\text { Users do influence } \\
\text { Users Intention on }\end{array}$ \\
\hline Hyporesearch & Ordinal & 12 & 60.149 & 18.549 & 0.534 & Ho & buying books online \\
\hline
\end{tabular}

\section{CONCLUSION}

From the research conducted, there are some conclusions that can be obtained regarding with the factors influence Indonesian Internet users intention on buying books online which are as follows.

1. The features of online bookstores such as the availability of book catalogue, customer service, search function, shopping chart, book’ synopsis, readers’ review, and discount price have influence to Indonesian's Internet users intention on buying books online

2. Web design of online bookstores, which consist of the attractiveness of its colors, artistic factors, layout, visual effect and typography do not influence the intention of Indonesian Internet Users on buying books online.

3. Convenience factors of online bookstores, such as the capability to provide its customers with the easiness of shopping from wherever and whenever they want (no time and place limitation); the capability to provide the wide variety of books' choices, and the easiness for the customers to make price comparison between online bookstores influence in building positive intention of Indonesian Internet users on buying books online.

4. The security factors either the security of payment or security of personal information have high influence to Indonesian Internet Users' intention on buying books online

5. The age of Indonesian Internet users don't have influence to their intention toward buying books online.

6. The Indonesian Internet Users' education level influences their intention on buying books online.

7. The types of job occupied by the Indonesian Internet users influence their intention toward buying books online.

8. The range of income had by Indonesian Internet users influence their intention on buying books online.

9. There are some other factors beside factors that have been investigated in this research that inhibit Indonesian Internet Users on buying books online although their intention are high enough. These randomized factors are such as: cultural factors, personal limitation and considerations.

\section{REFERENCES}

Anonymous. 1999. "E-Commerce and the Evolution of Retail Shopping Behavior," Pulse of Customer, (Online) diakses tangggal 19 April 2001 dari http://www.cognitiative.com/research_publications/pulse_archives/res_pulse_archive_7 99.pdf 
2000. "Verdict on Electronic Shopping 2000", (Online), diakses tanggal 19 April 2001 dari http://www.verdict.co.uk/es2000.htm

2001. "Not All Site Features Turn Online Shoppers Into Buyers, PricewaterhouseCoopers' Survey Reports," PriceWaterHouseCoopers Retail Intelligence System $^{\circledR}$ (Online) diakses tanggal 20 May 2001 dari http://www.pwcris.com/freecontent/pressreleases/press28.asp

2001. "Sejarah Internet di Indonesia: Pertarungan Menjadi yang Pertama," DotCom. Edisi 22 Thn II, 24 April - 7 Mei 2001.

Boerhanoeddin, Zuraida. 2000. "E-Commerce in Indonesia," (Online) diakses tanggal 22 April 2001 http://www.isoc.org/inet2000/cdproceedings/7c/7c 3.htm

eCom Resource Center. 2001. "Creating Your Online Storefront,” (Online) diakes tanggal 11 April 2001 http://www.ecom/resourcecenter.com/build/createstorefront.html

Federal Networking Council. 1995. Internet Overview, Internet Monthly Report.

Fingar, P., Harsha Kumar, dan Tarun Sharma. 2000. Enterprise e-Commerce. Florida, USA: Meghan-Kiffer Press Tampa.

Godlinez, Victor. 2000. "Online Shopping World Expanding at Staggering Rate,” The NewsTimes Online Edition, (Online) diakses tanggal 24 April 2001 dari http://www.newstimes.com/archive2000/may24/bze.htm

Jackie, Pollok. 2001. "Food for Thought: The Online Shopping Experience," PriceWaterHouseCoopers, (Online) diakses pada tanggal 19 April 2001 dari http://www.pwcris.com

Kotler, Philip. 2000. Marketing Management: Analysis Planning, Implementation, and Control. New Jersey: The Millennium Edition, Prentice Hall.

Neuman, W. L. 2000. Social Research Methods: Qualitative and Quantitative Approaches. Fourth Edition. USA: Allyn and Bacon.

Nielsen, Jakob. 1999. "Why People Shop on the Web," diakses tanggal 22 Maret 2001 dari http://www.useit.com/alertbox/990207.html

Nissen E. Mark. 1995. Commerce Model and the Intelligent Hub. CommerceNet.

O’Brien, James A. 1999. Management Information Systems: Managing Information Technology in The Internet Worked Enterprise. Fourth Edition. USA: McGraw-Hill Book Companies.

Ravi, Kalakota and Andrew B. Whinston. 1996. Readings in Electronic Commerce. Addison Wesley. 
Retail Intelligence Systems. 2001. "Online Privacy Concern Paramount: PriceWaterhouseCoopers Survey Reports,” (Online), diakses April 2001 dari http://www.pwcris.com/freecontent/pressreleases/press26.asp

Sembiring, Dalyantta. 2001. “Belanja Buku Menghemat Waktu.” PC Media. Vol 1 No.9 Agustus.

Singarimbun, Masri dan Sofian Effendi (ed.). 1989. Metode Penelitian Survai (Edisi Revisi). Jakarta: LP3ES.

Singgih, Santoso. 2001. Riset Pemasaran: Konsep dan Aplikasi dengan SPSS. Jakarta: Elex Media Komputindo.

Sugiyono. 1999. Metode Penelitian Bisnis. Bandung: Alfabeta.

Sunarsip. 2001. "Lonceng Kematian e-Business dan Kebangkitannya Kembali.” Manajemen. Edisi No. 152, April.

Umar, Husein. 2000. Metode Penelitian untuk Skripsi dan Tesis Bisnis. Jakarta: RajaGrafindo Persada.

Wahyudi, Purbo dan Wahyudi A.A. Onno. 2001. Mengenal e-Commerce. Jakarta: Elexmedia Komputindo. 